JURNAL PENDIDIKAN USIA DINI

DOI: https://doi.org/10.21009/JPUD.112
DOI:https://doi.org/10.21009/JPUD.112.04

\title{
KONTRIBUSI PERMAINAN KONSTRUKTIVIS (MEDIA BALOK) DENGAN PENINGKATAN KEMAMPUAN KOGNITIF
}

\author{
FAISAL RACHMAT \\ Universitas Al-Azhar Indonesia \\ J1. Sisingamangaraja No.1,Selong, Kby. Baru, Kota Jakarta Selatan \\ Email:faisal.insansolusi@gmail.com
}

\begin{abstract}
This classroom action research aims to determine the improvement of cognitive skills through playing blocks. The research subjects were children in group A \& B Age 3-6 Years old of RA. Nurul Amiin, in a total of 23 children consisting of 9 Girls andl4boys. Researchers use classroom action research methods with observation and documentation to collect data. Analysis of the data used in this research is the analysis of descriptive and qualitative.The results showed an increased ability of the students cognitive at $90 \%$ based on the evaluation of the results on the first cycle and second cycle.It can be concluded that the implementation of learning by utilizing blocks media to improve children's cognitive abilities can be implemented in the learning process.
\end{abstract}

Keywords: Blocks media, Cognitive ability

\begin{abstract}
Abstrak: Penelitian tindakan kelas ini bertujuan untuk mengetahui adanya peningkatan kemampuan kognitif anak melalui bermain balok. Subjek penelitian adalah anak kelompok B usia 3-6 tahun di RA. Nurul Amiin, Citayam, Depok yang berjumlah 23 anak terdiri dari 9anak perempuan dan 14 anak lakilaki. Peneliti menggunakan metode penelitian tindakan kelas dengan observasi dan dokumentasi untuk mengumpulkan data. Analisa data yang digunakan dalam penelitian ini adalah analisis deskriptif kualitatif. Hasil penelitian menujukkan adanya peningkatankemampuan kognitifanaksebesar $90 \%$ berdasarkan evaluasi hasil dari siklus I dan siklus II. Sehingga dapat disimpulkan bahwa pelaksanaan pembelajaran dengan memanfaatkan media balok untuk meningkatkan kemampuan kognitif anak dapat diimplementasikan dalam proses belajar.
\end{abstract}

Kata kunci:Media balok, Kemampuan kognitif.

\section{PENDAHULUAN}

Anak usia dini adalah sosok individu yang unik yang berada pada rentang usia 0-8 tahun. Pada masa ini disebut "Gold Periode" yakni anak berada pada periode keemasan perkembangan dan pertumbuhan. Hal ini dikarenakan pertumbuhan dan perkembangan anak pada masa ini bergerak dengan cepat dan merupakan dasar bagi perkembangan tahap selanjutnya (Jawati, R.,2013). Perkembangan dan pertumbuhan pada anak usia dini 
terdiri dari beberapa aspek, salah satu aspek yang penting dimiliki anak adalah kognitif. Aspek ini dikatakan penting karna akan berhubungan dengan perkembangan kreativitas dan imajinasi anak untuk menyesuaikan diri dengan lingkungan. Salah satu bentuk kemampuan kognitif dalam kehidupan social anak adalah dalam bentuk pemikiran abstraksi yang disebut juga dengan skema kognitif. Skema kognitif dilukiskan sebagai struktur dasar proses berpikir.

Suatu contoh skema tersebut adalah apa yang disebut skema klasifikasi. bila anak berusia 3-7 tahun dihadapkan dengan sekumpulan gambar bunga merah dan bunga putih, mak nampak dengan jelas bahwa anak mengerti adanya klasifikasi kelompok bunga merah dan kelompok bunga putih. Jadi anak ternyata sudah memiliki sejumlah struktur dasar dengan integrasi yang baik seperti mengumpulkan berbagai objek dalam klasifikasi tertentu serta cara mengatur secara hierargik berbagai kelompok dalam klasifikasi tersebut (Rita, K. 2012).
Dengan melihat kemampuan anak mengklasifikasikan objek melalui permainan. Dengan bermain, anak menjadi terangsang untuk mengeksplorasikan daya imaginasi. Imajinasi adalah kemampuan individu menggabungkanelemen dari pengalaman dalam situasi tertentu yang menghasilkan prilaku yang baru. Hal ini penting dalam pembentukan kreativitas (Dita, 2014). Seperti penelitian Sabta (2010), aktivitas anak dalam pelaksanaan pembelajaran dengan memanfaatkan media balok untuk meningkatkan kemampuan kognitif anak pada siklus 1 menunjukkan persentase $50 \%$ dan meningkat pada siklus 2 menjadi $85 \%$ ini berarti anak termotivasi dan merasa senang sekali dalam mengikuti proses pembelajaran. Anak-anak melakukan bermain secara individu ataupun berkelompok.

Anak yang bermain secara individu hanya akan beinteraksi dan menunjukkan ketertarikan dalam mengeksplorasi dan memanipulasi objek mainannya sendiri. Lebih jauh lagi, bermain menggunakan objek juga 
Kontribusi Permainan Konstruktivis... Faisal Rachmat

membantu perkembangan kreatifitas dan pemecahan masalah (Merdiana, 2014).

Balok adalah peralatan standar yang harus ada dalam ruang kelas anak usia dini dan sangat penting untuk mengimplementasikan kurikulum yang kreatif. Unit block (balok satuan) adalah balokbalok kecil dengan berbagai bentuk, dapat memberikan kegiatan belajar yang memungkinkan anak memahami konsepkonsep yang dibutuhkan dalam matematika antara lain geometri, seni, kreativitas, sosial emosional dan lainnya (Sabta,2010)

Pada penelitian ini akan diangkat mengenai kontribusi permainan konstruktif dengan kemampuan kognitif pada anak usia 3 s/d 6 tahun.Berdasarkanhasil observasi yang saya lakukan pada tiga subyek siswa/i RA. Nurul Amiin bahwa, peneliti menemukan kontribusi permainan konstruktivis (media balok) dengan kemampuan kognitif anak.Hal ini menjadi perhatian karena kemampuan kognitif anakdipengaruhi oleh lingkungan pendidikan informal.Dalam hal ini yang sangat berperan adalah keluarga yaitu lingkungan kehidupan pertama dan langsung berhubungan dengan anak. Dalam lingkungan keluarga yang paling berpengaruh terhadap kemampuan kognitif terutama pembentukan imajinasi yang cenderung stabil. Sebaliknya bila lingkungan keluarga tidak memberikan kesempatan yang positif maka akan berakibat kemampun kognitif anak cenderung negatif.

Tujuan penelitian ini untuk mendeskripsikan kontribusi permainan konstruktivis (media balok) dengan peningkatan kemampuan kognitif anak usia dini 3 s.d. 6 tahun, dan gambaran faktor-faktor yang meningkatkan kemampuan kognitif melalui permainan konstruktivis (media balok) anak usia dini 3 s.d. 6 tahun di RA. Nurul Amiin, Bojong Gede, Bogor.

\section{KAJIAN TEORITIK}

\section{Pengertian Kemampuan kognitif}

$\begin{array}{lrr} & \text { Kemampuan kognitif } & \text { adalah } \\ \text { suatu proses berpikir, } & \text { yakni } \\ \text { kemampuan individu } & \text { untuk } \\ \text { menghubungkan, menilai dan }\end{array}$


mempertimbangkan suatu kejadian atau peristiwa meliputi mengelompokkan benda yang memiliki persamaan warna, bentuk, ukuran dan mencocokan bentuk lingkaran, segitiga, segiempat dan mengenali angka(Jawati, 2013).

Kemampuan kognitif adalah kemampuan individu untuk menghubungkan, menilai dan mempertimbangkan suatu kejadian atau peristiwa yang mempengaruhi faktor herditas, kematangan, pembentukan imajinasiminat bakat dan kebebasan individu dalam berkreasi (Rita,2012).

Hal ini diperkuat oleh pernyataan Yunikowati (2014), kemampuan kognitif adalah kemampuan individu dalam berpikir yang melibatkan kreativitas dalam memecahkan suatu masalah, bersifat otomatis dan cepat dalam menemukan solusi-solusi baru. Salah satunya pemahaman konsep matematika pada anak usia dini yang perlu sekali stimulasi.

Ahli lain Dita (2014), Kemampuan kognitif adalah suatu proses berfikir, yaitu kemampuan individu untuk menghubungkan, menilai dan mempertimbangkan suatu kejadian atau peristiwa. Kemampuan perkembangan kognitif antara lain mengelompokkan benda yang memiliki persamaan warna, bentuk, dan ukuran, mencocokkan lingkaran, segitiga, dan segiempat serta mengenali dan menghitung angka 1 sampai 20 .

Selain itu, Kemampuan kognitif merupakan satu atau beberapa kemampuan untuk memperoleh dan menggunakan pengetahuan dalam rangka memecahkan masalah dan beradaptasi dengan lingkungannya seperti bermain balok. Balok adalah peralatan standar yang harus ada dalam ruang kelas anak usia dini dan sangat penting untuk mengimplementasikan kurikulum yang kreatif. Unit block (balok satuan) adalah balokbalok kecil dengan berbagai bentuk, dapat memberikan kegiatan belajar yang memungkinkan anak memahami konsepkonsep yang dibutuhkan dalam matematika antara lain geometri, seni, 
Kontribusi Permainan Konstruktivis... Faisal Rachmat

kreativitas, sosial emosional dan lainnya (Sabta, 2010).

Berdasarkan uraian teori diatas, maka peneliti menyimpulkan bahwa kemampuan kognitif adalah implementasi pengetahuan individu dalam mengeksplorasikan berbagai pemikiran, pilihan gagasan, memainkan ide, mencoba alternatif dengan memodifikasi hasil yang kreatif seperti bagaimana ketika murid berimajinasi membuat menara yang tinggi seperti hotel dan gedung-gedung bertingkat, membuat kereta api yang panjang, membuat rumah/kantor dan sebagainya.

Faktor-faktor yang dapat mengembangkan kemampuan kognitif anak

(1) Eksplorasi pemikiran, meliputi pilihan gagasan, memainkan ide, mencoba alternatif dan memodifikasi hasil kreasi.(2)Imajinasi keterampilan kognitif, yakni daya konstruktif individu dalam mengeksplorasinya melalui balok (Sabta,2010).

\section{Definisi Permainan Konstruktivis} (media balok)
Menurut Merdiana (2014), bermain konstruktif adalah suatu bentuk permainan untuk membangun dan menciptakan suatu karya nyata yang ada dalam pikiran anak dengan menggunakan bahan misalnya, lego (balok), puzzle, geometri dan sebagainya tanpa memikirkan manfaat melainkan mendapatkan kesenangan yang di peroleh dari membuatnya.Hal ini di perkuat oleh Perwitasari (2013), Bermain plastisin sama halnya dengan bermain balok yang disebut juga permainan konstruktifis.

Kegiatan bermain konstruktifis merangsang kreativitas dan imajinatif anak.Anak harus membayangkan bentuk yang akan dibuat cita rasa seni dibutuhkan sehingga hasilnya enak dilihat. Permainankonstruktifis membantu anak menjadi kreatif sehingga anak yang kreatif itu akan mampu dan menjadi: Lancar berpikir, fleksibel dalam berpikir, orisinil (asli) dalam berpikir, elaborasi, imaginatif, senang menjajaki lingkungannya, banyak ajukan pertanyaan, mempunyai rasa ingin tahu yang kuat, suka melakukan 
eksperimen, suka menerima rangsangan baru, berminat melakukan banyak hal, tidak mudah merasa bosan.

Ahli lain Hurlock (1998), bermain konstruktif adalah permainan dimana anak-anak menggunakan bahan untuk membuat sesuatu yang bukan tujuan bermanfaat melainkan lebih ditujukan bagi kegembiraan yang diperoleh dari membuatnya. Anakanak membutuhkan alat permainan konstruksi dan peralatan bermain bentuk yang dipersiapkan di taman kanak-kanak hendaknya memberi kebebasan aktivitas kepada anak untuk mengekspresikan dirinya melalui visualisasi dan imajinasinya seperti; bermain balok atau lego.

Berdasarkan uraian teori diatas, peneliti menyimpulkan bahwa permainan konstruktivis adalah pola penciptaan imajinasi individu yang diwujudkan dalam bentuk bangunan suatu benda melalui media balok maupun lego demi memperoleh hasil karya yang kreatif.

Faktor-faktor yang $\begin{array}{r}\text { dapat } \\ \text { mengembangkan } \\ \text { konstruktivis (media balok) }\end{array}$

Menurut Merdiana (2014) terdapat faktor faktor yang dapat mengembangkan permainan konstruktivis (media balok):

Reproduktif, yakni anak memproyek objek yang dilihatnya dalam kehidupan sehari-hari atau dalam media masa ke dalam bentuk konstruksinya, misalnya kue dari tanah liat untuk mewakili kue yang dilihatnya di rumah atau di dalam buku kuliner; (2) Produktif, yakni melalui bermain balok ataupun bahan mainan yang digunakan anak;

Kegembiraan, yakni suatu perasaan anak ketika membuat suatu bangunan melalui balok.

\section{Dinamika Kontribusi Permainan Konstruktivis dengan kemampuan kognitif Siswa/i RA. Nurul Amiin, Citayam, Depok.}

Berdasarkan kajian dari berbagai teori yang dilakukan peneliti, dapat disimpulkan bahwa dinamika kontribusi permainan konstruktivis dengan kemampuan kognitif Siswa/i adalah nilai psikologis siswa/i ketika menciptakan suatu bentuk bangunan melalui balok. Hal ini sesuai dengan 
Kontribusi Permainan Konstruktivis... Faisal Rachmat

penelitian terdahulu seperti penelitian Perwitasari (2013), menyatakan bahwa Anak harus membayangkan bentuk yang akan dibuat cita rasa seni dibutuhkan sehingga hasilnya enak dilihat. Lalu penelitian Sabta (2010) menyatakan bahwa kemampuan kognitif merupakan satu atau beberapa kemampuan untuk memperoleh dan menggunakan pengetahuan dalam rangka memecahkan masalah dan beradaptasi dengan lingkungannya seperti bermain balok. Lalu penelitian Rita (2012), kemampuan kognitif adalah kemampuan individu untuk menghubungkan, menilai dan mempertimbangkan suatu kejadian atau peristiwa yang mempengaruhi faktor herditas, kematangan, pembentukan imajinasi minat bakat dan kebebasan individu dalam berkreasi.

\section{METODE PENELITIAN}

\section{Waktu dan Tempat Penelitian}

Lokasi penelitian adalah objek penelitian dimana kegiatan penelitiandilakukan. Peneliti melakukan penelitian ini di RA. Nurul Amin Komplek Lembah Griya nomor 20, Kelurahan Raga Jaya, Kecamatan Bojong Gede Kota Bogor.Penelitimemilih di lingkunganinikarenaterdapatanak-anak yang berusia3-6 tahun yang merupakan AUD, sehinggamemudahkanpenelitiuntukme ncariinformasitentangkontribusi permainan konstruktivis dengan peningkatan kemampuan kognitifanakusiadini yang berada di komplekini.

Penelitian ini berlangsung selama 3 bulan, yaitu pada bulan April hingga bulan juni 2017. Adapun pelaksanaan tindakan dilaksanakan dari tanggal 1020 April 2017. Pelaksanaan tindakan memerlukan waktu 2 minggu yaitu pada minggu kedua dan ketiga bulan April. Pelaksanaan tindakan dilakukan dengan dua siklus. Pada siklus I, pertemuan pertama dilaksanakan pada hari senin tanggal 10 April 2017, pertemuan kedua dilaksanakan padahari selasa tanggal 11 April 2017, pertemuan ketiga dilaksanakan pada hari rabu tanggal 12 April 2017, dan 
pertemuan keempat dilaksanaakan pada hari kamis tanggal 13 April 2017. Sementara itu pada siklus II, pertemuan pertama pada hari senin pada tanggal 17 April 2017, pertemuan kedua dilaksanakan pada hari selasa tanggal18 April 2017, pertemuan ketiga dilaksanakan padahari rabu tanggal 19 April 2017, dan pertemuan keempat pada hari kamis pada tanggal 20 April 2017.

\section{Subjek Penelitian}

Berdasarkan permasalahan yang peneliti kaji, yaitu Subjek penelitian adalah anak-anak yang berada di RANurul Amin Komplek Lembah Griya nomor 20, Kelurahan Raga Jaya, Kecamatan Bojong Gede Kota Bogor. Anak kelompok A dan B yang berjumlah 23 orang anak, yaitu 14 orang anak laki-laki dan 9 orang anak perempuan.

\section{Metode}

Penelitian ini menggunakan jenis Penelitian tindakan kelas (PTK). Penelitian tindakan kelas merupakan penelitian yang reflektif terhadap berbagai aksi atau tindakan yang dilakukan oleh guru mulai dari perencanaan sampai penilaian terhadap tindakan nyata di dalam kelas yang berupa kegiatan belajar mengajar untuk memperbaiki kondisi pembelajaran yang dilakukan (Kemendiknas, 2010: 194).

Teknik pengumpulan data dalam penelitian kualitatif yang terpenting untuk digunakan adalah: rencana tindakandan dokumentasi: (1) Observasi, dilakukan bersamaan dengan pelaksanaan kegiatan pembelajaran. Data yang dibutuhkan dalam penelitian ini berupa data kualitatif yang diisi berdasarkan pengamatn di lapangan (Myrnawati,2016). (2) Dokumentasi yang dilakukan dalam penelitian ini menggunakan foto hasil kegiatan dari pembelajaran di setiap siklus yang telah dilakukan.

Instrumen yang digunakan dalam penelitian ini, yaitu menggunakan lembar observasi. Lembar observasi aktivitas anak digunakan untuk memantau setiap perkembangan anak mengenai kemampuan bermain konstruktif dengan bermain balok dan geometri 
Kontribusi Permainan Konstruktivis... Faisal Rachmat

yang menjadi patokan dalam pengukuran kemampuan kognitif anak.

\section{Analisis Data}

Analisis data yang dilakukan

untuk mengetahui keefektifan suatu kegiatan pembelajaran yang dilakukan.

Pada penelitian tindakan kelas ini digunakan analisis deskripsi kuantitatif, yaitu suatu metode penelitian yang bersifat menggambarkan kenyataan atau fakta sesuai dengan data yang diperoleh dengan tujuan untuk mengetahui peningkatan bermain kionstruktif dalam meningkatkan kemampuan kognitif anak. Analisis data dihitung dengan menggunakan statistik yang sederhana yaitu:

\section{Lembar Observasi}

Lembar observasi aktivitas anak yang disusun untuk mengetahui keaktifan anak selama kegiatan pembelajaran berlangsung. Lembar observasi aktivitas anak digunakan sebagai acuan pengamatan dalam mengetahui kekurangan-kekurangan yang dilakukan oleh anak pada saat proses belajar mengajar berlangsung dan sebagai pedoman untuk

\begin{tabular}{|c|c|c|c|}
\hline No & $\begin{array}{c}\text { Kriteria } \\
\text { penilaian }\end{array}$ & $\begin{array}{c}\text { Skor } \\
\text { nilai }\end{array}$ & $\begin{array}{c}\text { Kisaran } \\
\text { skor }\end{array}$ \\
\hline 1 & $\begin{array}{c}\text { Berkembang } \\
\text { sangat baik }\end{array}$ & 4 & $3.6-4$ \\
\hline 2 & $\begin{array}{c}\text { Berkembang } \\
\text { Sesuai } \\
\text { Harapan }\end{array}$ & 3 & $3.4-3.5$ \\
\hline 3 & $\begin{array}{c}\text { Mulai } \\
\text { berkembang }\end{array}$ & 2 & $2.4-3.2$ \\
\hline 4 & $\begin{array}{c}\text { Belum } \\
\text { berkembang }\end{array}$ & 1 & $0-2.2$ \\
\hline
\end{tabular}

Penilaian Rata-rata

Penilaian rata-rata ini diperoleh peneliti dengan cara menjumlahkan nilai yang diperoleh anak kemudian dibagi dengan jumlah anak di kelas. Nilai rata-rata didapat dengan menggunakan rumus: 
$x=\sum \times \div \sum \mathrm{N}$ dengan:

$\mathrm{X}=$ nilai rata2.

$\sum \times=$ jumlah semua nilai anak

$\Sigma \mathrm{N}=$ jumlah anak Merdiana, $\mathrm{F}$. (2014)

\section{Penilaian untuk ketuntasan belajar}

Terdapat dua kategori ketuntasan belajar, yaitu secara perorangan dan secara klasikal. Ketuntasan belajar secara perorangan dikatakan tuntas jika anak masuk dalam kategori baik atau nilai minimal 4. Sementara itu ketuntasan klasikal dapat dikatakan tuntas jika presentase mencapai $75 \%$ untuk tiap aspeknya. Untuk menghitung presentase ketuntasan belajar digunakan rumus:

Jumlahsiswatuntas Ketuntasan = BelajarJumlah siswa

Tabel 3.2. kriteria keberhasilan belajar anak usia 3 s/d 5 tahun \%

\begin{tabular}{|l|l|}
\hline$\geq 80 \%$ & Sangat tinggi \\
\hline $60-79 \%$ & Tinggi \\
\hline $40-59 \%$ & Sedang \\
\hline $20-39 \%$ & Rendah \\
\hline$\leq 20 \%$ & Sangat rendah \\
\hline
\end{tabular}

Indikator Keberhasilan
Penelitian tindakan kelas ini dikatakan berhasil apabila:

1). $75 \%$ anak dari jumlah 23 orang anak mampu menuangkan ide ke dalam bentuk dan warna berdasarkan hasil karya nyata yang dibuat oleh anak.

2). $75 \%$ anak dari jumlah 23 orang mampu memadukan warna dan bentuk berdasarkan hasil karya nyata yang dibuat oleh anak.

3).75\% anak dari jumlah 23 orang anak mampu menunjukan bagianbagian bentuk dan warna berdasarkan fungsinya.

4).75\% anak dari jumlah 23 orang anak mampu menunjukkan hasil kreasi menjadi sebuah bangunan berdasarkan hasil karya nyata yang di buat oleh anak.

HASIL DAN PEMBAHASAN

Tabel 4.1gambaran umum subyek penelitian

\begin{tabular}{|l|l|}
\hline Jenis kelamin & Siswa/i \\
\hline Laki-laki & 14 \\
\hline Perempuan & 9 \\
\hline Jumlah & 23 \\
\hline
\end{tabular}


Kontribusi Permainan Konstruktivis... Faisal Rachmat

Berdasarkan tabel 4.1 diatas bahwa jumlah siswa sebesar 14 orang dan siswi sebesar 9 orang.

Tabel 4.2 gambaran skor pengamatan siklus satu pada siswa/i

\begin{tabular}{|c|c|c|}
\hline $\begin{array}{c}\text { Kriteria } \\
\text { penilaian }\end{array}$ & Skor & Siswa/i \\
\hline BSB & 4 & 1 \\
\hline BSH & 3 & 0 \\
\hline MB & 2 & 4 \\
\hline BB & 1 & 18 \\
\hline Jumlah & -- & 23 \\
\hline
\end{tabular}

Berdasarkan tabel 4.2 diatas bahwa pada pertemuan pertama aspek 1 anak yang mendapat skor 1 ada 18 anak, pada aspek 2 ada 4 anak mendapat skor 2, pada aspek 3 yang mendapat skor 3 sebanyak 0 anak, pada aspek 4 seluruh anak mendapat skor 4 sebanyak 1 anak. Sedangkan pada pertemuan kedua aspek 1 ada 14 anak, pada aspek 2 ada 6 anak yang mendapat skor 2, pada aspek 3 ada 2 anak yang mendapat skor 3, dan aspek 4 seluruhnya anak mendapat skor4 ada 1 anak.

Sehingga dapat disimpulkan bahwa pada siklus 1 ini pada aspek 4 yaitu anak melakukan ekspolrasi sendiri melalui media balok mendapat skor yang paling rendah, hal ini dikarenakan masih banyak anak yang belum bisa melakukan eksplorasi sendiri dengan media balok.

Pada siklus II pertemuan pertama aspek I ada 16 anak yang mendapat skor 4, aspek 2 ada 3 anak yang mendapat skor 3 , pada aspek 3 ada 2 anak yang mendapatskor 2 , pada aspek 4 ada 2 anak yang mendapatskor skor 1. Sedangkan pertemuan kedua aspek 1 yang mendapat skor 4 sebanyak 20 anak, aspek 2 yang mendapatskor 3 sebanyak 1 anak, aspek 3 yang mendapat skor 2 sebanyak 1 anak, dan aspek 4 yang mendapat skor 1 sebanyak 1 anak. Berdasarkan analisis data pemanfaata dan media balok anak pada siklus 1 dann siklus 2 diperoleh prosentase dari $50 \%$ mengalami peningkatan sebesar $80 \%$.

\section{Pembahasan}

Dengan metode bermain balok mempermudah peningkatan kemampuan kognitif anak karena kegiatan bermain ini merangsang anak mengembangkan idenya membentuk bangunan-bangunan yang lebih 
menarik karena balok melengkapi balok satuan membentuk bangunan yang lebih dramatis.

Hal ini sesuai dengan pendapat riset Piaget dalam Sabta (2010), membagi 4 tingkat perkembangan kemampuan untuk berpikir mengembangkan pengetahuan yaitu tahapan sensomotorik, praoperasional konkret, operasional konkret dan operasional formal. Anak taman kanak-kanak berada pada tahapan praoperasional, karena anak telah menggunakan logika pada tempatnya. Balok mempunyai tempat di hati anak serta menjadi pilihan favorit sepanjang tahun bahkan sampai tahun ajaran berakhir.

Ketika bermain balok banyak temuantemuan terjadi. Demikian pula pemecahan masalah terjadi secara alamiah. Bentuk konstruksi mereka yang sederhana sampai yang rumit dapat menunjukkan adanya peningkatan berpikir mereka. Daya penalaran anak akan bekerja aktif.

Hasil analisis data pada siklus 1 pertemuan 1 mencapai nilai rata-rata sebesar $35 \%$ dan pertemuan kedua mencapai nilai rata-rata sebesar 50\%.
Dari analisis data tersebut, dapat dilihat bahwa ada peningkatan kemampuan kognitif anak dari siklus 1 pertemuan 1 dan pertemuan 2. Karena kemampun kognitif anak pada siklus1 mencapai $75 \%$ seperti yang diharapkan oleh peneliti, maka peneliti melanjutkan penelitian lagi pada siklus 2.

Hasil analisis data pada penelitian siklus 2 pertemuan 1 mencapai nilai rata2 sebesar $80 \%$ dan pertemuan 2 mencapai nilai rata2 sebesar 90\%.Maka dapat dilihat bahwa ada peningkatan kemampuan kognitif dari hasil penelitian siklus 1 dan siklus 2 . Karena kemampuan kognitif sudah mencapai $89 \%$ maka peneliti mengakhiri penelitian ini pada siklus 2.

\section{KESIMPULAN DAN SARAN}

Berdasarkan hasil penelitian yang telah diuraikan, maka dapat disimpulkan bahwa aktivitas anak dalam pelaksanaan pembelajaran dengan memanfaatkan media balok untuk meningkatkan kemampuan kognitif anak pada siklus 1 
Kontribusi Permainan Konstruktivis... Faisal Rachmat

menunjukkan persentase $50 \%$ dan meningkat pada siklus 2 menjadi 90\% ini berarti anak termotivasi dan merasa senang sekali dalam mengikuti proses pembelajaran.Kemampuan kognitif anak usia 3-6 tahun dalam pelaksanaan pembelajaran dengan memanfaatkan media balok pada siklus 1 menunjukkan prosentase $50 \%$ dan meningkat pada siklus 2 menjadi $95 \%$ ini berarti dari dua indikator yang diteliti diantaranya menyebutkan bentuk-bentuk geometri dan membuat bentuk bangunan secara bervariasi mengalami peningkatan.

Dalam proses pembelajaran guru diharapkan berbagai media yang bervariasi suatu cara dalam pembelajaran di RA Nurul Amin. Diharapkan kegiatan ini dapat dilakukan secara berkesinambungan dan bersinergi dengan kegiatan lain yang lebih kreatif dan inovatif.

\section{DAFTAR PUSTAKA}

Allen. Jane, Cheryl, Maryln. Diciplin Positive (terjemahan), Jakarta: Prestasi Pustaka Karya, 2006.

Dita, K.S. Meningkatkan Kemampuan Kognitif Melalui Permainan
Klasifikasi Berdasarkan

Warna. Bengkulu: Jurnal pendidikan. Vol.03 no.04. april 2012 FIP UN, 2014.

Hurlock. Pengantar psikologi perkembangan. USA: Mc graw hill, 1998.

Jawati, R. Peningkatan Kemampuan Kognitif Anak Melalui Permainan Ludo Geometri di PAUD Habibulo Ummi II. P adang: Jurnal Pendidikan Vol.1 no.1 April 2013 Fakultas Ilmu Pendidiikan UNP, 2013.

Kemendiknas. Panduan Pedoman Pembelajaran di PAUD. Jakarta: depdiknas, 2010.

Merdiana, F. Plementation of Constructive Playing to Improving Visual-spatial Intelligences for Children. Bengkulu: Jurnal Pendidikan Vol.05 No. 06. FIP UNB, 2014.

Myrnawati. Metode Penelitian Kualitatif. Jakarta: UNJ Press, 2013.

Perwitasari. Implementasi Permainan Plastisin Pada Anak Usia Dini di TK Ludo Bengkulu. Bengkulu: jurnal pendidkan Vol.05 no 07. FIP UNB, 2013.

Rita, K. Peningkatan kemampuan kognitir berbasis permainan konstruktivis. Bengkulu: Jurnal pendidikan. Vol.02 no.03. april 2012 FIP UNB, 2012.

Sabta, N. Pemanfaatan Media Balok Untuk Meningkatkan Kemampuan Kognitif Anak Usia 3-4 Tahun. Surabaya: Jurnal Pendidikan vol.04.2010. Fakultas Ilmu Pendidikan UNS, 2010. 
JURNAL PENDIDIKAN USIA DINI

Volume 11 Edisi 2, November 2017

Yunikowati, D.A. Peningkatan

Kemampuan Kognitif dalam

Mengenal Konsep Bilangan

Dengan Permainan Cetak

Angka Play Dough Pada Anak.

Semarang: Jurnal Ilmiah PG-

PAUD IKIP Veteran, Vol.2

No.2, 2014. 